\title{
Penerapan Teori Arsitektur Organik Dalam Strategi Perancangan Pusat Pengembangan Industri Kreatif Di Bandung
}

\author{
Song Prasetya Sujanra ${ }^{1 *}$, Ummul Mustaqimmah ${ }^{2}$, Agung Kumoro Wahyuwibowo ${ }^{3}$ \\ Program Studi Arsitektur, Fakultas Teknik, Universitas Sebelas Maret Surakarta ${ }^{1}$ \\ song.sujan@gmail.com* \\ Program Studi Arsitektur, Fakultas Teknik, Universitas Sebelas Maret Surakarta ${ }^{2}$ \\ Program Studi Arsitektur, Fakultas Teknik, Universitas Sebelas Maret Surakarta ${ }^{3}$
}

\begin{abstract}
Creative economy is becoming an important aspect for our future economy because it is based knowledge and creativity, which are renewable resources. Creative economy needs good quality of creative human resources (creative class) to improve. Indonesia has a huge number of population with $70 \%$ of total are working-aged population which are potential in promoting creative economy, yet, Indonesia's creative industry still can't compete globally. Some strategies are needed to improve the quality and the quantity of creative class in Indonesia. One of the strategies is by providing creative environment with creative space as medium. A well-designed space can increase motivation, expand creative tempo, entertains and inspires. Creative space should provide attention, stimulation and focus. To achieve such characteristics, Organic Architecture is considered as the right design approach. Organic Architecture principals are used in designing strategy, such as in site analysis, spatial analysis, mass organization, mass transformation and façade programming. Analytical process applying Organic Architecture principals produces the design of creative hub building that optimizes the creative process.
\end{abstract}

Keywords: creative economy, creative space, Organic Architecture

\section{PENDAHULUAN}

Potensi pasar karya kreatif di dalam dan luar negeri sangat besar dan memiliki kecenderungan untuk terus berkembang. Menurut data dari Badan Pusat Statistik dapat diketahui bahwa selama periode 2010-2013 industri kreatif menyumbang $7,8 \%$ terhadap pendapatan domestik bruto Indonesia. Selain itu, ekonomi kreatif juga berkontribusi sebesar $10,72 \%$ terhadap total penyerapan tenaga kerja dalam perekonomian pada tahun 2013.

Namun, daya saing industri kreatif Indonesia masih kurang. Nilai daya saing industri kreatif berdasarkan data dari RPJP Ekonomi Kreatif Indonesia (2014) Indonesia berada di rata-rata 4,4 dari 10 sehingga dapat disimpulkan bahwa diperlukan usaha dan percepatan pembangunan industri kreatif melalui ketujuh dimensi utama, salah satunya sumber daya kreatif. Kuantitas orang kreatif yang benar-benar mampu bersaing secara global masih kurang jumlahnya.
Melihat kondisi tersebut, diperlukan edukasi dan penanaman pola pikir kreatif yang lebih kontekstual dan diterapkan di segala sisi kehidupan. Hal tersebut dapat dicapai dengan menciptakan suatu iklim kreatif yang dapat didukung dengan infrastruktur, baik yang bersifat institusional maupun sarana fisik berupa ruang-ruang kreatif. Kiswandono (2005) menjelaskan bahwa selain lingkungan psikis, ruang secara fisik dapat memfasilitasi aktivitas mengubah ide ke produk kreatif.

Lloyd (2009) menyebutkan beberapa hal yang harus disediakan oleh ruang kreatif untuk menumbuhkan iklim kreatif, yaitu suatu ruang kreatif harus memunculkan Attention (Atensi), Stimulation (Stimulasi), dan Focus (Fokus). Arsitektur dalam hal ini tentu saja berperan dalam menciptakan atmosfer yang inspiratif dan kreatif. Hal ini dapat dapat dicapai dengan menghadirkan intervensi fisik suatu ruang yang dapat menimbulkan pemandangan dan kesan yang dramatik dan tidak biasa. Perencanaan dan 
perancangan ruang tersebut memerlukan suatu metoda disain agar persoalan-persoalan fisik dan non fisik tersebut dapat terselesaikan secara arsitektural. Oleh karena itu, penerapan Arsitektur Organik dipilih sebagai pendekatan arsitektural dalam proses perencanaan dan perancangan bangunan pusat pengembangan ekonomi kreatif tersebut.

\subsection{Arsitektur Organik}

Arsitektur Organik merupakan sebuah konsep arsitektur yang diilhami dari alam. Terdapat dua pengertian Arsitektur Organik menurut Fleming, Honour \& Pevsner. Pertama, Arsitektur Organik menurut mereka adalah sebuah istilah yang diaplikasikan pada bangunan atau bagian dari bangunan yang terorganisir berdasarkan analogi biologi atau yang dapat mengingatkan pada bentuk natural. Misalnya arsitektur yang menggunakan bentuk-bentuk biomorfik. Pengertian kedua, Arsitektur Organik menurutnya adalah sebuah istilah yang digunakan oleh Frank Lloyd Wright, Hugo Haring, dan arsitek lainnya untuk arsitektur yang secara visual dan lingkungan saling harmonis, terintegrasi dengan tapak, dan merefleksikan kepedulian arsitek terhadap proses dan bentuk alam yang diproduksinya. (Rasikha, 2009)

Terdapat beberapa konsep dasar Arsitektur Organik menurut Pearson (2002) yang dapat dijelaskan sebagai berikut:

\section{a. Building as nature}

Bangunan Arsitektur Organik bersifat alami, di mana alam menjadi pokok dan inspirasi dari Arsitektur Organik. Bentuk bangunan Arsitektur Organik terinspirasi dari ketidaklurusan organisme biologis.

\section{$b$. Continuous present}

Arsitektur Organik merupakan sebuah desain yang terus berlanjut. Arsitektur Organik tidak pernah berhenti dan selalu dalam keadaan dinamis namun tetap membawa unsur keaslian dalam sebuah desain.

c. Form follows flow

Keunikan bentuk bangunan Arsitektur Organik juga dikarenakan Arsitektur Organik merupakan arsitektur form follow flow (bentuk mengikuti energi). Bentuk bangunan dengan Arsitektur Organik mengikuti aliran energi dari alam, menyesuaikan alam sekitarnya secara dinamis, bukan melawan alam. Alam dalam hal ini dapat berupa angin, cahaya dan panas matahari, arus air, energi bumi dan lainnya.

\section{d. Of the people}

Selain energi dari alam, desain Arsitektur Organik juga dipengaruhi oleh hubungan dengan pemakai bangunan. Desain Arsitektur Organik dipengaruhi oleh aktifitas-aktifitas yang diwadahi pada bangunan, tujuan bangunan, kebutuhan pengguna, kenyamanan penggunanya dan keinginankeinginan penggunanya. Steadman (2008) mengatakan bahwa salah satu ide yang melekat pada Arsitektur Organik adalah pada metode komposisi yang bekerja dari dalam ke luar, yakni dari program kebutuhan penghuni dan harapan mengenai penampilan luar bangunan.

e. Of the hill

Frank Lloyd Wright menyebutkan bahwa suatu bangunan dengan site lebih baik berhubungan secara 'of the hill' dibandingkan dengan 'on the hill'. Of the hill di sini memiliki arti bahwa bangunan merupakan bagian dari site, bukan sekedar bangunan yang ditempatkan di atas sebuah site.

\section{f. Of the materials}

Asitektur organik juga dapat diekspresikan melalui material yang digunakan. Menurut Steadman dalam Rasikha (2009) ada kecenderungan penggunaan material tertentu dalam Arsitektur Organik. Material yang dipilih antara lain material alami, material lokal dan material yang dapat memproduksi bentuk bebas. Tsui dalam Rasikha (2009) menjabarkan beberapa kategori material untuk arsitektur yang perancangannya berbasis alam, yaitu menggunakan material yang dapat memiliki beberapa fungsi sekaligus (sebagai interior dan eksterior), penggunaan material daur ulang dalam konstruksi, dan jika mungkin, gunakan material bangunan yang tidak beracun dan desainnya dapat mengurangi polusi dalam bangunan.

\section{g. Youthful and unexpected}

Arsitektur Organik biasanya memiliki karakter yang inkonvensional, profokatif, terlihat muda, menarik dan mengandung keceriaan anak-anak. Tsui dalam Rasikha (2009) mengatakan, unsur-unsur yang dapat ditemukan pada bangunan organik antara lain adalah: perubahan, pergerakan fisik dari komponen-komponen bangunan, kontinuitas struktur dan tampak, ruang yang terbuka dan beragam, denah dengan grid yang tidak 
seragam, serta fluktuasi pada level lantai.

\subsection{Pusat Pengembangan Industri Kreatif}

Kehadiran lingkungan inspiratif sangat dibutuhkan masyarakat dalam proses menghasilkan ide-ide kreatif. Kiswandono dalam Manisyah (2005) mengatakan bahwa ruang secara fisik dapat memfasilitasi aktivitas mengubah ide ke produk kreatif yang nyata. Ruang fisik ini berupa ruang yang inspiratif yang memfasilitasi individuindividu kreatif dalam menciptakan, mengembangkan dan memasarkan produk kreatifnya. Selain itu, ruang tersebut juga dapat berperan untuk mendorong interaksi manusia dimana manusia dapat bertukar pendapat dan nilai-nilai sehingga mereka dapat saling belajar dan mempengaruhi.

European Creative Hubs Forum (2015) mengategorikan aktivitas-aktivitas yang harus diwadahi oleh sebuah ruang kreatif adalah sebagai berikut:

- business support

- networking

- research

- communication, dan

- talent support.

Arsitektur sebagai disiplin ilmu, tentu berperan dalam penciptaan dan pengembangan lingkungan dan ruang-ruang kreatif. Lloyd (2009) menyebutkan beberapa hal yang harus disediakan oleh ruang kreatif untuk menumbuhkan iklim kreatif, yaitu suatu ruang kreatif harus memunculkan Attention (Atensi), Stimulation (Stimulasi), dan Focus (Fokus). Hal tersebut dapat diwujudkan dengan menciptakan ruang yang fleksibel dan menciptakan suatu perasaan atau kesan tertentu. Ruang kreatif haruslah memberikan kenyamanan namun juga memberikan suatu sensasi baru yang tidak biasa dan dapat mengubah orientasi dan memberikan pandangan yang baru bagi penggunanya. Contohnya adalah melalui desain-desain dinding yang tidak vertikal, lorong-lorong yang tidak lurus, dan ruangruang yang tidak berbentuk kotak. Landry dalam Manisyah (2009) juga menyatakan bahwa intervensi fisik yang menarik memberikan pengaruh penting dalam memberikan inspirasi bagi masyarakat suatu kota.

\section{METODE}

Objek desain pusat pengembangan industri kreatif ini dirancang dengan menerapkan strategi desain dari teori Arsitektur Organik untuk dapat mencapai fungsi bangunan yang optimal. Dalam tahap perencanaan dan perancangan bangunan Pusat Pengembangan Industri Kreatif di Bandung, dibutuhkan metode-metode dalam tahapan pengumpulan data hingga analisis data. Data-data tersebut akan menjadi bahan pertimbangan untuk keputusan desain bangunan Pusat Pengembangan Industri Kreatif di Bandung. Metode pengumpulan data yang dilakukan adalah dengan tinjauan lapangan dan studi preseden guna mendapatkan pola aktivitas dan kebutuhan ruang pada bangunan pusat pengembangan industri kreatif. Langkah kedua adalah studi literatur terhadap teori Arsitektur Organik.

Setelah mendapatkan kebutuhan ruang berdasarkan kebutuhan dari pusat pengembangan industri kreatif, langkah selanjutnya adalah menguraikan aplikasi prinsip-prinsip Arsitektur Organik yang dapat diterapkan pada bangunan pusat pengembangan industri kreatif. Prinsipprinsip ini kemudian disintesa kembali untuk dapat menentukan strategi perancangan dalam menjawab persoalan desain dari pusat pengembangan industri kreatif dengan hasil sebagai berikut:

a. Persoalan Tapak

Persoalan tapak dibagi ke dalam dua sub bab yaitu pemilihan tapak dan pengolahan tapak. Pengolahan tapak yang dimaksud adalah mengenai bagaimana respon desain di dalam pengolahan tapak terpilih. Prinsip Arsitektur Organik yang digunakan adalah of the hill dan continuous present. Hubungan bangunan dan site akan dicapai melalui karakter dan kondisi iklim pada tapak, aspek ekologis dan tata lansekap. Aspek ekologis bangunan organik akan dimunculkan pada sistem pencahayaan dan penghawaan yang dapat memaksimalkan pencahayaan dan penghawaan alami. Aspek ekologis juga dapat ditampilkan melalui tata lansekap.

b. Persoalan Peruangan

Persoalan peruangan menerapkan prinsip of the people. Kualitas ruang bangunan 
pusat pengembangan industri kreatif dipengaruhi oleh gaya internal yaitu aktivitas pengguna, kenyamanan pengguna, kebutuhan ruang, dan kriteria ruang dan zoning ruang. Pendekatan organik juga akan dimunculkan dengan menerapkan prinsip youthful and unexpected melalui penataan layout ruang, bentuk ruang yang beragam, juga fluktuasi pada level lantai yang beragam.

c. Persoalan Bentuk dan Tata Massa Bangunan

Persoalan bentuk dan tata massa membahas bagaimana menciptakan bentuk bangunan yang atraktif dengan menerapkan prinsip building as nature, sehingga bentuk bangunan terinspirasi dari ketidaklurusan organisme dan alam. Persoalan bentuk dan tata massa bangunan juga menerapkan prinsip form follows flow sehingga bangunan menyesuaikan gaya eksternal, seperti kondisi cuaca dan iklim site.

d. Persoalan Tampilan Bangunan

Tampilan bangunan dipengaruhi oleh material dan ornamen. Material yang akan digunakan adalah material material yang dapat menciptakan bentuk-bentuk bebas dan material yang dapat berfungsi sebagai interior maupun eksterior. Ornamen yang digunakan pun tidak hanya berfungsi sebagai penghias tetapi juga sebagai bagian struktural yang konstruksional atau merupakan pengembangan dari material yang digunakan.

\section{HASIL DAN PEMBAHASAN}

\subsection{Building as Nature}

Prinsip arsitektur organik building as nature diterapkan untuk menjawab persoalan bentuk bangunan. Ekspresi massa bangunan sesuai dengan pendekatan Arsitektur Organik akan lebih menekankan pada bentuk-bentuk biomorfik yang dinamis dan cenderung memiliki grid yang tidak teratur. Massa bangunan menggunakan bentuk-bentuk yang fleksibel dan dinamis untuk memunculkan Atensi dan Stimulasi dari penggunanya dengan menciptakan suatu kesan dan pengalaman ruang tertentu.

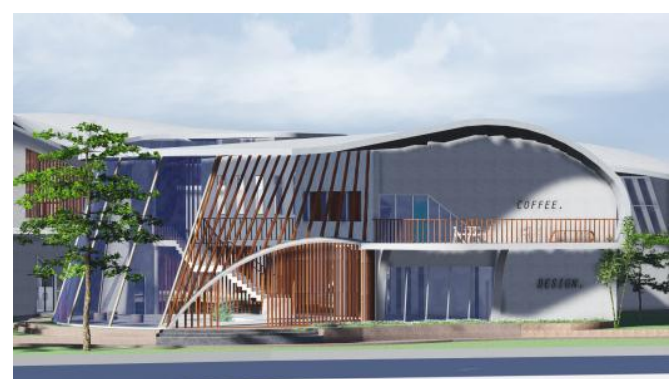

Gambar 2. Bentuk bangunan banyak menggunakan bentuk lengkung untuk mengekspresikan ketidaklurusan alam

Sistem struktur bangunan mempertimbangkan sistem struktur yang dapat mendukung bentukbentuk biomorfik.

Struktur atap yang digunakan oleh bangunan adalah menggunakan atap struktur space frame karena sifatnya yang fleksibel sehingga dapat menghasilkan bentuk-bentuk organik yang dinamis.

Supper structure yang digunakan dalam bangunan pusat pengembangan industri kreatif mempertimbangkan dimensi ruang, ketinggian lantai, kekuatan dan juga efektifitas struktur. Struktur yang terpilih adalah rigid frame.

Sub structure yang digunakan pada bangunan menggunakan pondasi footplate.

\subsection{Form Follows Flow}

Prinsip form follows flow diterapkan pada persoalan bentuk dan tata massa bangunan. Bentuk dan penataan massa bangunan pusat pengembangan industri kreatif mempertimbangkan energi eksternal seperti matahari dan angin.

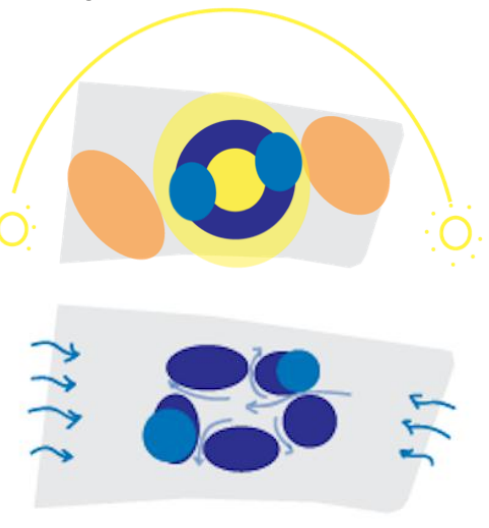

Gambar 3. Respon tata Massa Bangunan terhadap Energi Eksternal Tapak

Selain energi eksternal, bentuk tata massa bangunan juga mempertimbangkan energi internal. Bangunan pusat pengembangan industri kreatif yang direncanakan memiliki beberapa kelompok fungsi kegiatan yang kemudian 
digabungkan ke dalam kelompok massa. Massamassa tersebut kemudian akan dihubungkan secara terpusat dengan suatu ruang-ruang sosial (social space) seperti komunal dan taman. Menggunakan pola dan sistem tata massa seperti ini dapat mendukung terjadinya interaksi sosial dan kolaborasi.

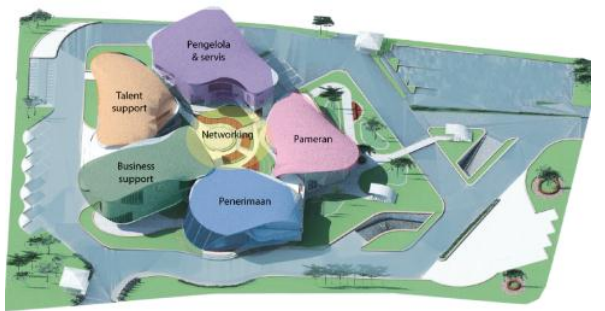

Gambar 4. Tata Massa Bangunan Terpusat

\subsection{Of The People}

Kebutuhan ruang di dalam pusat pengembangan industri kreatif ini didasari oleh aktivitas yang dilakukan oleh pelaku kegiatan. Aktivitas dari pelaku-pelaku kegiatan tersebut membutuhkan ruang khusus di dalamnya, dari keseluruhan aktivitas/ kegiatan yang dilakukan oleh berbagai macam pelaku tersebut yang akan dibahas rinci adalah tentang kegiatan pembelajaran yang disesuaikan dengan kurikulum yang digunakan. (lihat Tabel 1)

Tabel 1. Kelompok Kegiatan dan Kebutuhan Ruang

\begin{tabular}{|c|c|}
\hline Kelompok Ruang & Ruang \\
\hline \multicolumn{2}{|c|}{ Kelompok Kegiatan Penerimaan } \\
\hline \multirow{3}{*}{$\begin{array}{l}\text { Kelompok Ruang } \\
\text { Penerimaan }\end{array}$} & Parkir pengunjung \\
\hline & Parkir pengelola \\
\hline & Entrance hall \\
\hline \multicolumn{2}{|c|}{ Kelompok Kegiatan Utama } \\
\hline \multirow{6}{*}{$\begin{array}{l}\text { Kelompok Ruang } \\
\text { Business Support }\end{array}$} & Loker \\
\hline & Co-working space \\
\hline & Co-office space \\
\hline & Ruang rapat \\
\hline & Ruang pelatihan \\
\hline & Ruang entertainment \\
\hline \multicolumn{2}{|c|}{ Kelompok Kegiatan Penunjang } \\
\hline \multirow{3}{*}{$\begin{array}{l}\text { Kelompok Ruang } \\
\text { Talent Support }\end{array}$} & Ruang seminar \\
\hline & Ruang workshop \\
\hline & Studio fotografi \\
\hline \multirow{4}{*}{$\begin{array}{l}\text { Kelompok } \\
\text { Pameran } \\
\text { Penjualan }\end{array}$} & Galeri Pameran Tetap \\
\hline & Galeri Pameran Temporer \\
\hline & $\begin{array}{ll}\text { Ruang } & \text { Penyimpanan } \\
\text { Koleksi } & \end{array}$ \\
\hline & Art shop \\
\hline \multirow{2}{*}{$\begin{array}{l}\text { Kelompok Ruang } \\
\text { Networking }\end{array}$} & Komunal \\
\hline & Atrium \\
\hline \multirow[t]{3}{*}{ Café \& restoran } & Dapur dan ruang cuci \\
\hline & Area makan \\
\hline & Kasir \\
\hline Perpustakaan & Area penerimaan \\
\hline
\end{tabular}

Area baca

Kelompok Kegiatan Pengelola dan Servis

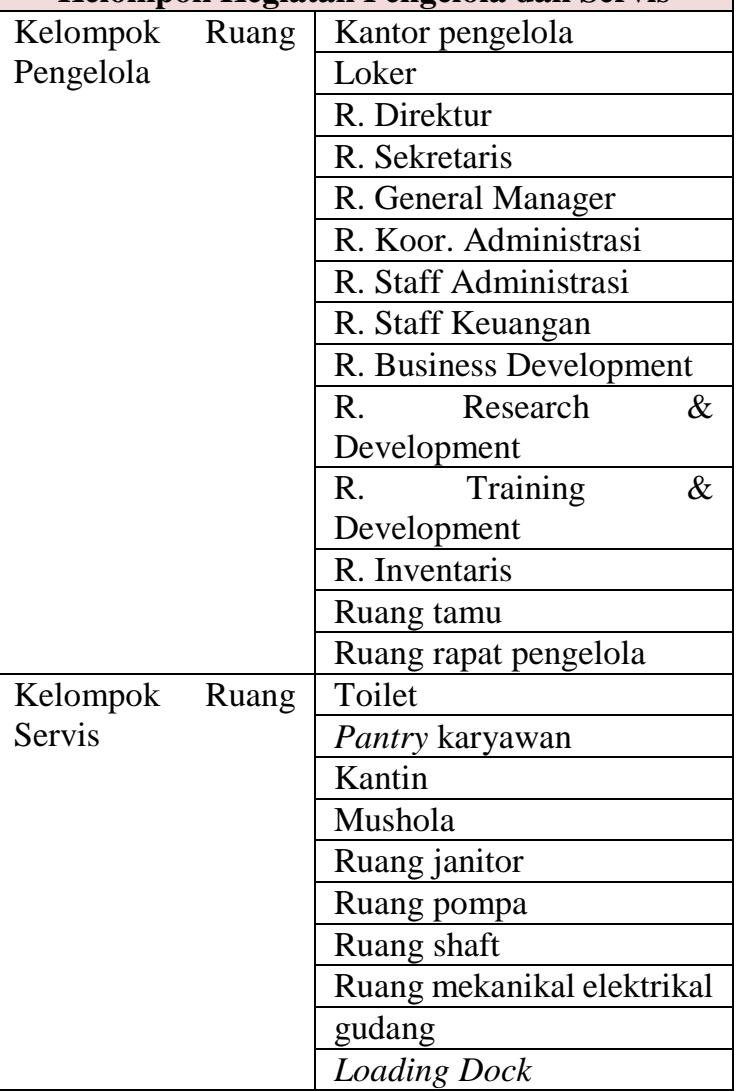

Setelah kebutuhan ruang telah ditentukan berdasarkan aktivitas yang diwadahi, ditentukan organisasi ruang berdasarkan hubungan kedekatan antar ruang sebagai penentu kualitas sebuah ruang dalam efisiensi mewadahi aktivitas pengguna.

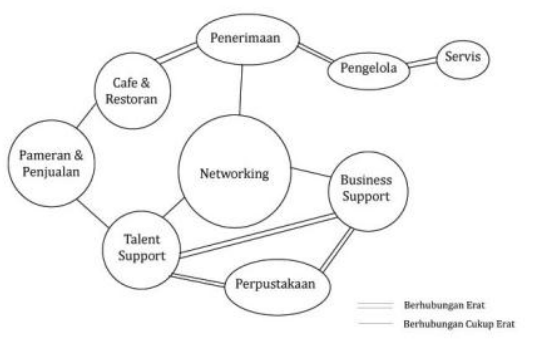

Gambar 5. Organisasi Ruang

\subsection{Of The Hill}

Of the hill memiliki arti bahwa bangunan merupakan bagian dari site, bukan sekedar bangunan yang ditempatkan di atas sebuah site. Prinsip arsitektur organik of the hill dilakukan dengan analisa pencapaikan, iklim dan lingkungan tapak untuk mendapatkan respon desain yang tepat terhadap kondisi tapak. Analisa pencapaian site dilakukan bertujuan untuk menentukan main entrance (ME) dan side entrance (SE) sebagai jalan masuk menuju site 
yang sesuai dengan kondisi lingkungan di sekitarnya. Penentuan ME dan SE dipengaruhi oleh sirkulasi dan arah pergerakan lalu lintas di sekitar site.

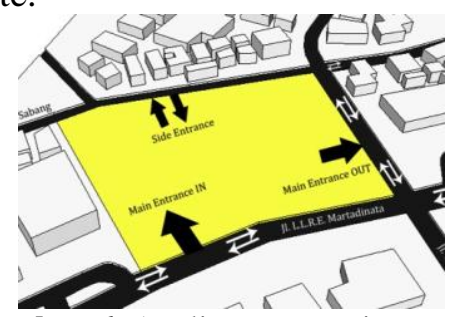

Gambar 6. Analisa Pencapaian Tapak

Analisis iklim dan lingkungan akan meliputi analisis tentang matahari, angin dan kebisingan lingkungan.

Analisis sinar matahari dilakukan untuk mengondisikan kenyamanan bangunan, konfigurasi ruang dan massa bangunan agar keberadaan sinar matahari dapat masuk dengan optimal namun juga tidak mengganggu kenyamanan pelaku kegiatan dalam bangunan.

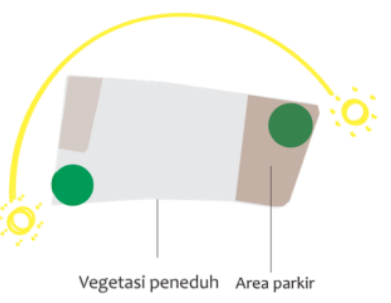

Gambar 7. Analisa Matahari dan Respon Desain Analisis orientasi angin dilakukan untuk mengondisikan kenyamanan penghawaan bangunan dengan menentukan respon desain agar angina dapat memasuki seluruh bangunan dalam tapak.

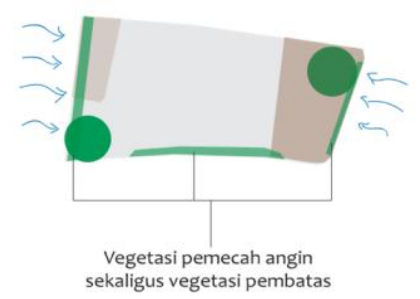

Gambar 8. Analisa Angin dan Respon Desain Sedangkan analisis angin bertujuan untuk mengantisipasi kebisingan dari luar site terhadap ruang-ruang tertentu yang memiliki kebutuhan ruang yang tenang atau dengan tingkat kebisingan rendah.

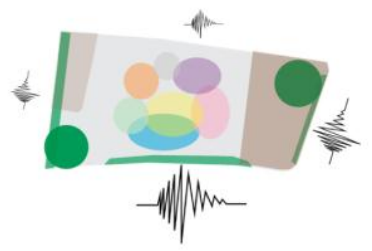

Gambar 9. Analisa Kebisingan dan Respon Desain

\subsection{Youthful and Unexpected}

Prinsip youthful and unexpected diterapkan pada pemilihan bentuk ruang. Bentuk dasar ruang menggunakan bentuk-bentuk yang fleksibel bertujuan untuk menciptakan suatu ruang gerak yang luwes dan leluasa sehingga memudahkan adanya interaksi-interaksi dan kolaborasi.

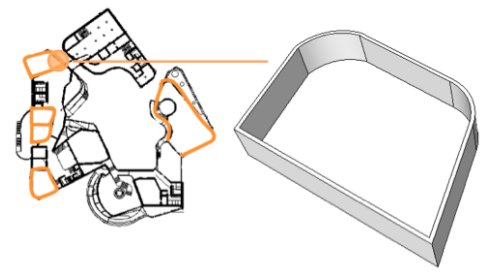

Gambar 10. Karakteristik Bentuk Dasar Ruang

Selain itu, prinsip youthful and unexpected juga diterapkan melalui permainan dimensi ruang. Tinggi rendahnya dimensi suatu ruang dapat menciptakan suatu kesan-kesan ruang yang tertentu. Hal ini bisa dicapai melalui permainan ketinggian plafond dan lantai, juga penggunaan void dan mezzanine. Ruang yang sangat tinggi memberikan kesan yang monumental, sedangkan ruang yang terlalu rendah akan membuat pengguna merasa tertekan. Pada ruang-ruang seperti pada co-working space dan komunal, jarak langit-langit dibuat tinggi untuk mengesankan keterbukaan. Sedangkan untuk ruang-ruang seperti ruang pelatihan, ruang seminar dan lainnya, langit-langit tidak dibuat terlalu tinggi untuk memunculkan kesan intim dan fokus.

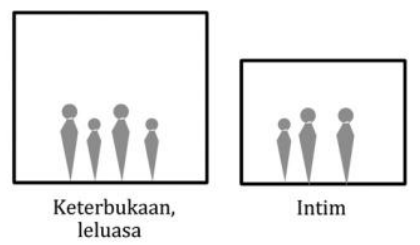

Gambar 11. Dimensi Ruang

\subsection{Continuous Present}

Penerapan prinsip continuous present dilakukan dengan memaksimalkan pencahayaan dan penghawaan alami bangunan, sehingga mengurangi penggunaan cahaya dan penghawaan buatan. Hal tersebut dapat dicapai dengan menerapkan hal-hal berikut:

- Pencahayaan

- Perencanaan dimensi dan orientasi bukaan

- Pengaturan ketinggian dan jarak antar massa bangunan 
- Penggunaan sun shading dan secondary skin untuk mengurangi panas dan silau dari matahari

- Penghawaan

- Pengaturan bukaan dan bentuk bukaan

- Penggunaan ventilasi silang

- Penataan vegetasi sekitar bangunan

Analisis tata lansekap dilakukan untuk mendapat pola tatanan lansekap yang berfungsi sebagai ruang terbuka hijau dan sekaligus sebagai penyelaras antara site dan massa bangunan. Terdapat elemen vegetasi dan juga elemen perkerasan yang digunakan dalam penataan lansekap bangunan. Elemen vegetasi dapat digunakan sebagai elemen peneduh, pengarah, penyejuk maupun groundcover.

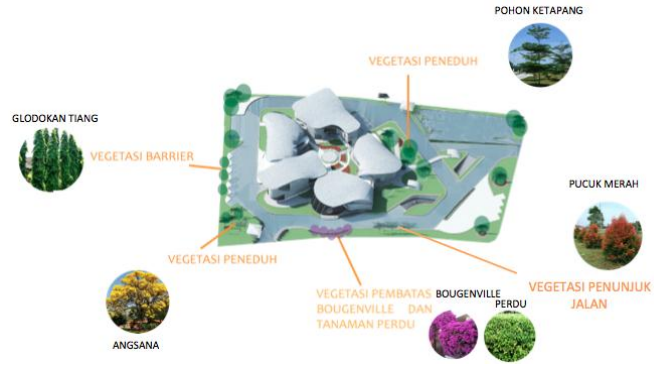

Gambar 12. Rancangan Tata Lansekap

\subsection{Of The Material}

Material bangunan yang digunakan pada bangunan yang direncanakan sesuai dengan pendekatan Arsitektur Organik menggunakan material-material yang dapat menciptakan bentuk-bentuk fleksibel dan dapat digunakan sebagai interior maupun eksterior seperti beton pracetak dan juga kayu.

Bangunan pusat pengembangan industri kreatif yang direncanakan harus fleksibel dan terbuka pada perubahan. Bangunan pusat pengembangan industri kreatif akan banyak mewadahi kegiatankegiatan pameran dan acara-acara kreatif lainnya. Oleh karena itu, tidak terlalu banyak ornamen-ornamen yang digunakan pada bangunan agar pengguna dapat menyesuaikan sesuai keinginan dan kebutuhannya. Ornamen yang digunakan pun menjadi satu dengan bangunan, tidak hanya sebagai elemen penghias, tetapi juga sebagai bagian struktural yang konstruksional atau merupakan pengembangan dari material yang digunakan.

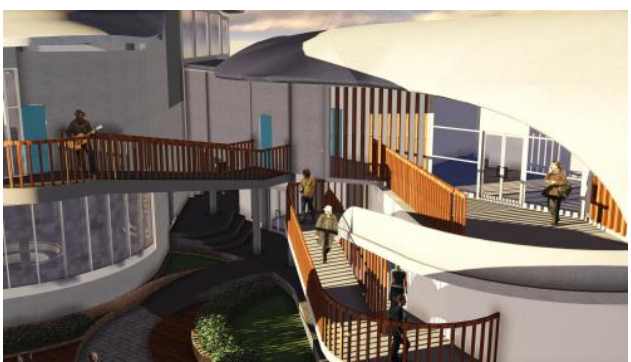

Gambar 13. Tampilan Bangunan

\subsection{Hasil Akhir}

Pusat Pengembangan Industri Kreatif yang dirancang akan menghadirkan suatu ruang kreatif di Kota Bandung yang difokuskan pada kegiatan industri desain, industri fesyen dan industri barang seni kerajinan. Prinsip-prinsip Arsitektur Organik diaplikasikan pada setiap persoalan desain dan diharapkan dapat mengoptimalkan proses pembelajaran yang terjadi di Pusat Pengembangan Industri Kreatif ini, sehingga dapat meningkatkan kualitas maupun kuantitas sumber daya kreatif Indonesia khususnya Kota Bandung.

Metode strategi perancangan Arsitektur Organik dan proses analisis yang dilakukan menghasilkan sebuah desain rancangan Pusat Pengembangan Industri Kreatif di Kota Bandung dengan pendekatan Arsitektur Organik sebagai berikut.

Nama Bangunan :Pusat Pengembangan Industri Kreatif

Lokasi : Jl. L. L. R.E. Martadinata, Bandung Wetan, Kota Bandung

Luas Lahan $\quad: 9.440 \mathrm{~m}^{2}$

Luas Bangunan : $7,465.6 \mathrm{~m}^{2}$

Kegiatan :business support, talent support, networking, memamerkan dan memasarkan karya.

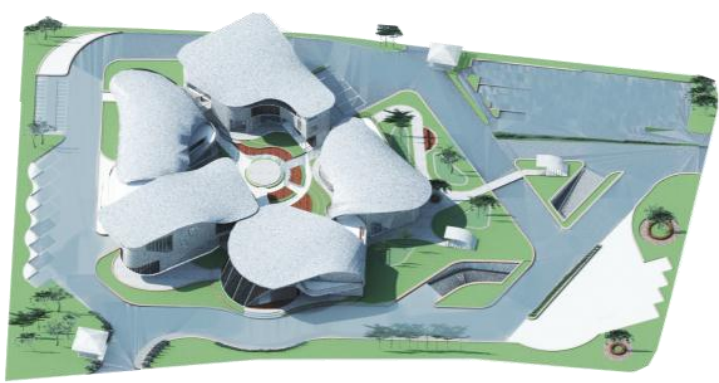

Gambar 14. Perspektif Keseluruhan Bangunan 


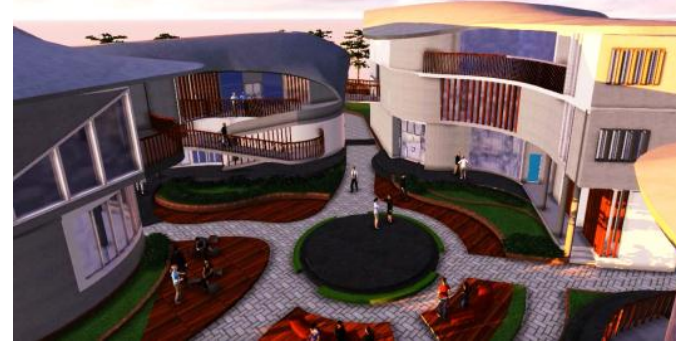

Gambar 15. Perspektif Eksterior Atrium

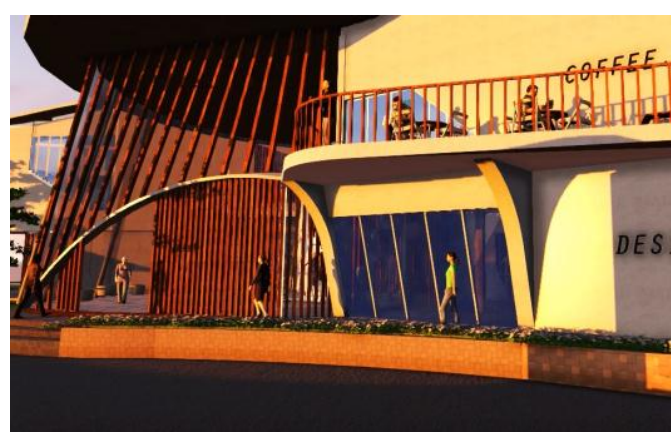

Gambar 16. Perspektif Eksterior Entrance Hall

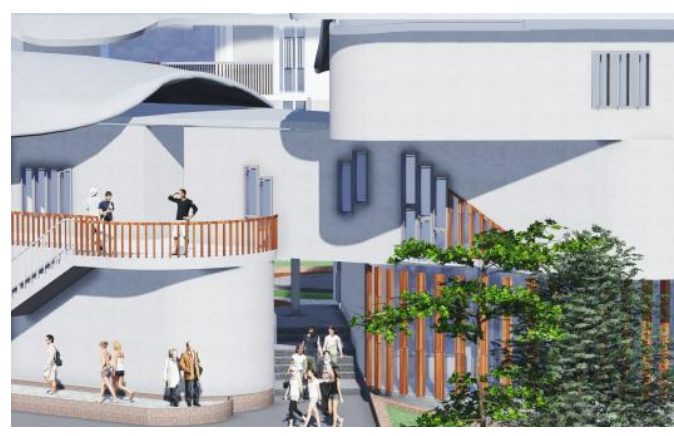

Gambar 17. Permainan Bentuk dan Tata Massa

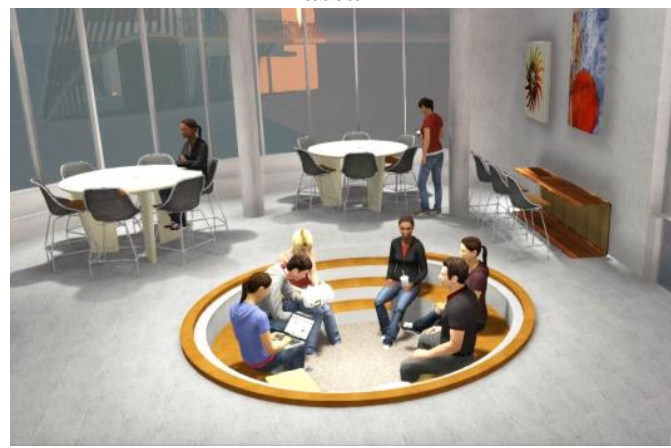

Gambar 18. Interior Area Co-working Space

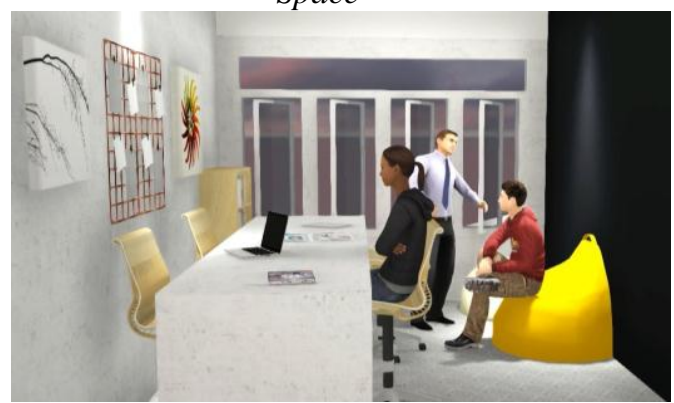

Gambar 19. Interior Area Co-office Space

\section{KESIMPULAN}

Penerapan Arsitektur Organik dalam perancangan bangunan Pusat Pengembangan Industri Kreatif di Bandung memerlukan perhatian secara menyeluruh baik pada faktor internal maupun eksternal. Faktor internal adalah tentang pelaku dan kegiatan yang diwadahi pada bangunan. Selain faktor internal, bangunan juga memperhatikan faktor eksternal seperti karakteristik lingkungan dan iklim tapak.

Pendekatan Arsitektur Organik merupakan sebuah metode perancangan yang tepat untuk diterapkan pada perancangan Pusat Pengembangan Industri Kreatif karena sesuai dengan kriteria ruang kreatif untuk memunculkan Atensi, Stimulasi dan Fokus.

\section{REFERENSI}

Evans, J. (2009). Creative Cities, Creative Spaces and Urban Policies.

https://www.researchgate.net/profile/Gr aeme_Evans/publication/228370244_Cr eative_Cities_Creative_Spaces_and_Ur ban_Policy/links/563b1eab08ae405111 a5a4ee.pdf diakses tanggal 10 Maret 2016.

Lloyd, Peter. 2009. Creative Space. http://www.catalystranchmeetings.com/ Thinking-Docs/Creative-Space-byPeter-Lloyd.pdf diakses tanggal 20 Maret 2017.

Manisyah, Miranti. 2009. Kota Kreatif: Penelusuran terhadap Konsep Kota Kreatif melalui Pengamatan Studi Kasus. Depok: Universitas Indonesia.

Pearson, David. 2002. New Organic Architecture.

www.ucpress.edu/books/pages/9678/96 78.intro.php diakses tanggal 10 Maret 2016

Rasikha, Tezza. 2009. Arsitektur Organik Kontemporer. Depok: Universitas Indonesia.

Steadman, Philip. 2008. The Evolution of Design: Biological Analogy in Architecture and Applied Arts; Revised Edition. New York: Routledge. 